\title{
Market integration of fresh milk in dairy business area of Pamijahan District and Cisarua District, Bogor Regency - Indonesia
}

\author{
C. Setianti, T. Ekowati and A. Setiadi \\ Faculty of Animal and Agricultural Sciences, Diponegoro University, \\ Tembalang Campus, Semarang 50275 - Indonesia \\ Corresponding E-mail: tiekowati@yahoo.com
}

Received May 04, 2016; Accepted February 12, 2017

\begin{abstract}
ABSTRAK
Penelitian ini bertujuan menganalisis integrasi pasar antar pasar komoditas susu di jalur distribusi susu di Kawasan Usaha Peternakan (KUNAK) Kecamatan Pamijahan dan Kecamatan Cisarua Kabupaten Bogor, Jawa Barat. Metode penelitian menggunakan metode survey. Simple random sampling adalah teknik sampling yang digunakan untuk menentukan responden dalam penelitian ini. Metode purposive adalah metode penentuan lokasi penelitian yang digunakan dalam penelitian ini. Jumlah responden dalam penelitian ini yaitu 80 peternak sapi perah di KUNAK and 90 peternak sapi perah di Kecamatan Cisarua. Data penelitian terdiri dari data primer dan data sekunder. Hasil penelitian menunjukkan uji kointegrasi Johansen Test harga susu pada peternak KUNAK Kecamatan PamijahanCisarua menunjukan hasil trace statistic sebesar 18,27 lebih besar dari nilai kritis 5\% sebesar 15,41. Uji kointegrasi Johansen Test harga susu pada tingkat koperasi (KPS dan KUD) terhadap IPS menunjukan hasil trace statistic sebesar 28,63 lebih besar dari nilai kritis 1\% sebesar 20,04. Hasil Uji Granger kausalitas menunjukkan bahwa adanya hubungan kausalitas di KUNAK Kecamatan Pamijahan dan Kecamatan Cisarua. Terdapat pengaruh kenaikan harga susu diantara KUNAK Kecamatan Pamijahan dan Kecamatan Cisarua pada tingkat IPS, artinya terjadi integrasi antara harga susu di tingkat IPS .

Kata kunci : harga susu, integrasi pasar, koperasi susu, sapi perah, susu segar
\end{abstract}

\begin{abstract}
The purpose of this study was to analyze the integration between dairy commodity market in milk distribution channels at Dairy Business Area, Pamijahan District and Cisarua District, Bogor Regency, West Java. The research method used was a survey method. Simple random sampling was a sampling technique used in this research to determine the respondent. Purposive method was a method that was used to determine research location. Respondents were 80 dairy cattle farmers at Dairy Business Area, Pamijahan District and 90 dairy cattle farmers at Cisarua District. Research data were consisted of primary data and secondary data. The results showed that the co-integration test in dairy farmers Dairy Business Area, Pamijahan District-Cisarua District trace statistic value of 18.27 was greater than 5\% critical value of 15.41 . The co-integration test in dairy cooperative level the trace statistic value of 28.63 was greater than $1 \%$ critical value of 20.04. Granger causality test results indicated that the results were a causality relation in Dairy Business Area, Pamijahan District and Cisarua District. There was an effect of the increase of milk price between Dairy Business Area, Pamijahan District and Cisarua District in Dairy Processing Industry Level, that's mean there was an integration between the milk price in Dairy Processing Industry level.
\end{abstract}

Keywords: dairy cattle, dairy cooperative, fresh milk, market integration, price of milk 


\section{INTRODUCTION}

Agricultural sector in Indonesia is a primary sector and has a high contribution for the economic development in Indonesia that the government should give a priority for agricultural sector in order to fulfill Indonesian people's food requirement to compensate the growth population which grow rapidly. Livestock is part of the agricultural sector that has an important role.

Dairy farm is a part of the agricultural sector which is an important sector that has added value to society (Sarker and Ghosh, 2010). The purpose of the dairy farm is to improve public nutrition, increase employment, improve milk production and increase the farmers' income (Siswadi et al., 2001).

Milk is a perishable agricultural commodity, it cannot be stored for a long time without being refrigerated or pasteurized or milk has to be made products that are not easily spoil (Jha et al. 2013). Meanwhile, market integration on agricultural commodity is an important thing in empirical study on economy development (Ghoshray and Ghosh, 2011).

Jha et al. (2013) stated that market integration makes the price signals different from one market and to another. A market also has rules on price changes. A weak or non-integrated market sometimes gives the wrong signals and affects the market to become inefficient market. Barret (2005) stated that well-integrated market plays an important role in economic policy.

Market system which is efficiently integrated will have positive relationship (correlation) among different market location all the time, that correlation directly measures how close is the price of a commodity moving together in different market locations. Mudikdjo et al. (1994) stated that milk prices are set in order to cover all of costs expenditure by the farmer. It means that the price level is set at a decent price level.

Bogor Regency is an area in West Java which has a centre of cow dairy milk production. Dairy cattle have a good prospect in Bogor Regency which is located in the highland/plateau that has a cold climate to run a dairy cattle farming. The population of these dairy cattle in Bogor Regency has increased, and the milk production also increased (Dinas Peternakan and Perikanan Kabupaten Bogor, 2013).

Dairy farmers produce fresh cow's milk. This fresh cow's milk should be immediately marketed because if fresh milk is stored in long periods of time it will turn sour and lose its good quality. Pamijahan District is one of dairy farming centre in Bogor Regency where Dairy Business Area are located. Cisarua District is another dairy farming centre in Bogor Regency.

Dairy cooperative role is to collect milk production from the dairy cows member and market it to Dairy Processing Industry. Dairy Product Cooperative Bogor is a dairy cooperative which collects milk from Dairy Business Area, Pamijahan District. Village Unit Cooperative Giri Tani is a dairy cooperative which collect the production of dairy cattle from Cisarua District farmer. The selling price of milk is determined by the markets which is in this case, cooperative and Dairy Processing Industry, where the price was determined by the quality of milk, the higher the quality of the milk, the higher the price of the milk. The selling milk price in farmers' level to cooperative in Dairy Business Area, Pamijahan District in 2011 is IDR 3,408/liter, in 2012 is IDR 3,429/liter and in 2013 is IDR 3,433/liter. Meanwhile in Cisarua District, the selling milk price in farmers level to cooperative was IDR 3,406/liter in 2011, and IDR 3,420/liter in 2012 IDR 3,430/liter in 2013. The selling price of milk in cooperative level to Dairy Processing Industry in Dairy Product Cooperative Bogor was IDR 4,508/liter in 2011, IDR 4,775/liter in 2012 and IDR 4,985/liter in 2013. The selling price of milk price in cooperative level to Dairy Processing Industry in Giri Tani village unit cooperative was IDR 4,408/liter in 2011, IDR 4,642/liter in 2012 and IDR 4,825/liter in 2013. Milk price fluctuations were determined by the market.

Based on this background, it is necessary to do research on market integration of fresh milk in milk path of dairy business area of two districts, those were in Pamijahan District and Cisarua District, Bogor Regency.

\section{MATERIALS AND METHODS}

\section{Method of Research}

Survey method was used in this research. To determine the respondent simple Random sampling was used in this research. The population of dairy farmers in Dairy Bussiness Area, Pamijahan District was 101 farmers, and the population of dairy farmers in Cisarua District was 120 farmers. Respondents were 80 dairy cattle farmers in dairy cattle farming Dairy Bussiness Area, Pamijahan District and 90 dairy cattle farmers in Cisarua Dictrict, counted using 
slovin calculation. The 80 farmers in Dairy Bussiness Area, Pamijahan District distributed fresh milk to Dairy Product Bogor Cooperative, and 90 farmers in Cisaura District distributed fresh milk to Giri Tani Cooperative Village Unit. Research locations were determined using purposive method, a method of sample selection based on certain criteria that are made for the object according to the aim of the research. The criteria of the selected locations were having dairy cattle business in Bogor Regency and having a dairy cooperative in the same area. Another criterias that Dairy Bussiness Area, Pamijahan District and Cisarua District have a lot of dairy farmers that distribute fresh milk to the two largest dairy cooperatives in Bogor, that are Dairy Product Cooperative Bogor and Viilage Unit Cooperative Giri Tani. Data collection method used in this study were observation and interview method. Primary and secondary data were collected in this study. Primary data were obtained from farmers in research location and relevant institutions such as dairy cooperative, which in this study, were Dairy Product Cooperative Bogor and Village Unit Cooperative Giri Tani in the form of time series data types over the last 3 years (2011-2013). Data time series in the last 3 years were monthly data, were 36 data in farmers level in Dairy Business Area, Pamijahan District and Cisarua District and cooperative level in Dairy Product Cooperative Bogor and Viilage Unit Cooperative Giri Tani. Secondary data were obtained from institution such as Dinas Peternakan and Perikanan Bogor Regency.

\section{Method Analysis}

The data collected were processed using descriptive statistical analysis of quantitative computed using the Unit Root Test with Eviews. Unit root test was used to test stationarity of time series data from each variable. To do this, Augmented Dickey-Fuller (ADF) test was used. Primary data which were time series data were used in this analysis. Asmara and Ardhiani (2010) stated that ADF (Augmented Dickey-Fuller) test equation was:

$$
\Delta \mathrm{Y}_{\mathrm{t}}=\alpha+\beta_{0} \mathrm{Y}_{\mathrm{t}-1}+\sum_{\mathrm{j}=1}^{\mathrm{m}} \beta_{\mathrm{j}} \Delta \mathrm{Y}_{\mathrm{t}-1}+\varepsilon_{\mathrm{t}}
$$

where:

$\mathrm{Y}_{\mathrm{t}} \quad$ : Variable of milk price in farmers level or Dairy Product Cooperative/Village Unit Cooperative level on $t$ period (IDR/liter)
$\mathrm{Y}_{\mathrm{t}-1} \quad$ : Variable of milk price in farmers level or Dairy Product Cooperative/Village Unit Cooperative level on the previous period (IDR/liter)

$\mathrm{Y}_{\mathrm{t}-1}$ : Variable of milk price in farmers level or Dairy Product Cooperative/Village Unit Cooperative level on $\mathrm{t}$ period reduce lag value (IDR/liter)

$\Delta \mathrm{Y}_{\mathrm{t}} \quad: \mathrm{Y}_{\mathrm{t}}-\mathrm{Y}_{\mathrm{t}-1}$

$\Delta \mathrm{Y}_{\mathrm{t}-1}: \mathrm{Y}_{\mathrm{t}-1}-\mathrm{Y}_{(\mathrm{t}-\mathrm{j})-1}$

M : Total lag

$\alpha \quad$ : Intercept

$\beta \quad$ : Parameter coefficient

$\varepsilon_{\mathrm{t}} \quad$ : Error term

Co-integration test was conducted using Johansen test. Trace test analysis was used in Johansen test. Test of trace test ( $\lambda$ trace) is a measuring the number of co-integration vectors in the data, using a matrix rank test of co-integration (Irawan and Rosmiyanti, 2007). According to Johansen and Julius (1990) test trace test ( $\lambda$ trace), is a likelihood ratio test to determined the most $r$ co-integration vectors, using a matrix rank test of co-integration, is:

$\lambda_{\text {trace }}(\mathrm{r})=\mathrm{T} \sum \sum_{\mathrm{t}=\mathrm{r}+1}^{\mathrm{p}} \operatorname{Ln}\left(1-\lambda_{\mathrm{i}}\right)$

where:

$\lambda_{\mathrm{i}}$ : Eigenvalue estimation that obtained from matrix estimation

$r$ : The rank that indicated the total of cointegration vector

$\mathrm{T}$ : Research time

Eagle-Granger test was used to prove that two price variables have a long term correlation. The model equation to examine the co-integration and price variables is (Asmara and Ardhiani, 2010):

$\mathrm{Y}_{\mathrm{it}}=\alpha+\beta \mathrm{X}_{\mathrm{jt}}+\mathrm{U}_{\mathrm{t}}$

where :

$\mathrm{Y}_{\mathrm{it}}$ : Variable of milk price in farmers level or Dairy Product Cooperative/Village Unit Cooperative level in i location on $t$ periode (IDR/liter)

$\alpha \quad:$ Intercept

$\beta$ : Parameter coefficient

$\mathrm{X}_{\mathrm{jt}}$ : Variable of milk price in farmers level or Dairy Product Cooperative/Village Unit Cooperative level in $\mathrm{j}$ location on $\mathrm{t}$ periode (IDR/liter)

$\mathrm{U}_{\mathrm{t}}$ : Deviation (error term) 


\section{RESULTS AND DISCUSION}

\section{Research Location}

The locations of the research were Dairy Business Area, Pamijahan District and Cisarua District. In Dairy Business Area, Pamijahan District, $37.5 \%$ of farmers (30 farmers) graduated from college. Most of the respondents, which were 49 farmers or $61.25 \%$, worked as dairy cattle farmers. Most of the farmers were 23-55 years old that 63 farmers or $78.75 \%$ still in productive age, and the majority of farmers (45 or $56.25 \%$ ) had more than 11 years of farming experience.

About $57.78 \%$ of the respondents (52 farmers) in Cisarua district graduated from elementary school, 55 farmers or $61.11 \%$ of the respondents had more than 11 years of farming experience, 74 farmers or $82.22 \%$ of the respondents were dairy cattle farmers. Most of the farmers were 23-55 years old and 68 farmers or $75.56 \%$ of them were still in productive age.

The locations of research were Dairy Business Area, Pamijahan District and Cisarua District. From the both locations the milk production was distributed to Dairy Product Cooperative Bogor and Giri Tani Village Unit Cooperative. Then, the milk production was distributed to Cimory.

\section{Stationery Data Test}

Augmented Dickey-Fuller test (ADF) was used for stationary data test to determine the stationary data of monthly milk price in farmers' level to cooperative level and from cooperative level to Dairy Processing Industry level. The research data were 36 data of the monthly milk price data from farmers' level to cooperative level and in cooperative level to Dairy level. The critical value level of ADF test monthly milk price in farmers level to cooperative level and in cooperative level to Dairy Processing Industry level at the intercept level was $1 \%$ and $5 \%$. The ADF test result for monthly milk is presented in Table 1.

For ADF test milk price in farmers level to cooperative level, $t$ statistic value of farmers in Dairy Business Area Pamijahan District-Cisarua District was $3.65 \%$ with a critical value of $\alpha=$ $1 \%$. For ADF test milk price in cooperative level to Dairy Processing Industry level, t statistic value of Dairy Product Cooperative Bogor- Village Unit Cooperative Giri Tani was $2.44 \%$ with a critical value of $\alpha=5 \%$. Based on the result of ADF test milk price in farmers level to cooperative level and in cooperative level to Dairy Processing Industry level, it was indicated that all variables used in this study has been stationary, and all of these variables will be tested by Johansen cointegration test.

\section{Integration of Milk Price Test}

Trace statistic value can be seen by using cointegration test using Johansen analysis test. Result of Johansen analysis test monthly milk price is shown in Table 2.

Co-integration of Johansen Test milk price in farmers level to cooperative level in Dairy Business Area, Pamijahan District-Cisarua District showed that the value of trace statistic was greater than critical value of 5\% namely 18.27>15.41. While, co-integration of Johansen Test milk price in cooperative level to Dairy Processing Industry level in Dairy Product Cooperative Bogor and Giri Tani village unit cooperative showed that the value of trace statistic was greater than critical value of $1 \%$, namely $28.63>20.04$.

The result of co-integration Johansen Test milk price in farmers level to cooperative level indicated that there was an integration of milk price between farmers level or cooperative level in this two areas, namely Dairy Business Area, Pamijahan District and Cisarua District. This was occurred because of the stable of relation among markets, integration market in short term and long term period and distribution fresh milk from Cisarua District and Dairy Business Area to Dairy Processing Industry Cimory and the various of dairy processing industries, respectively.

\section{Correlative Causality Test of Milk Price}

Granger Causality Test was used to know causality (reciprocal) between the variables. Granger Causality Test of milk price in farmers' level in Dairy Business Area, Pamijahan District and Cisarua District are presented in Table 3.

Based on Granger Causality Test, it is found that probability of F-statistic value farmers in Dairy Business Area Pamijahan District was greater than $\alpha=5 \%(0.960>0.05)$. It means that there was no effect on the changes of milk price in the farmers in Dairy Business Area, Pamijahan District to change of milk price the farmers in Cisarua District. Result of Granger Causality Test show that probability of F-statistic value farmers in Cisarua District was greater than $\alpha=5 \%(0.582$ $>0.05)$. It means that there was no effect on the changes of milk price the farmers in Cisarua 
Table 1. Augmented-Dickey Fuller (ADF) Test for Monthly Milk Price

\begin{tabular}{lcccccc}
\hline \multirow{2}{*}{ Market } & \multicolumn{2}{c}{ Price } & at Farmer Level & & \multicolumn{2}{c}{ Price at Cooperative Level } \\
\cline { 2 - 3 } \cline { 5 - 6 } & Lag & t-calculation & & Lag & t-calculation \\
\hline $\begin{array}{l}\text { Pamijahan District } \\
\text { Cisarua District }\end{array}$ & 3 & $3.65^{*}$ & & 4 & $2.44^{* *}$ \\
\hline
\end{tabular}

** critical value on $5 \%$; critical value on $1 \%$

Table 2. Co-integration Johansen Test Monthly Milk Price

\begin{tabular}{lcc}
\hline \multirow{2}{*}{ Market } & \multicolumn{2}{c}{ Trace Statistic } \\
\cline { 2 - 3 } & Price at Farmer Level & Price at Cooperative Level \\
\hline Pamijahan District & $18.27 * *$ & $28.63 *$ \\
Cisarua District & $* *$ critical value on $5 \% ; *$ critical value on $1 \%$ &
\end{tabular}

Table 3. Granger Causality Test Result Milk Price Farmers Level in Dairy Bussiness Area

\begin{tabular}{|c|c|c|c|c|}
\hline Causality Correlation & Observation & Lag & F-statistic & Probability \\
\hline $\begin{array}{l}\text { Milk price at farmers level in Dairy Bussiness } \\
\text { Area, Pamijahan District influence milk price of } \\
\text { Cisarua District }\end{array}$ & & & 0.04061 & 0.96025 \\
\hline $\begin{array}{l}\text { Milk price at farmers level in Cisarua District } \\
\text { influence milk price in Dairy Bussiness Area of } \\
\text { Pamijahan District }\end{array}$ & 34 & 2 & 0.55102 & 0.58228 \\
\hline
\end{tabular}

District to change of milk price the farmers in Dairy Business Area, Pamijahan District. From the result at Table 3 there was no reciprocal relation between Dairy Business Area, Pamijahan District and Cisarua District. it means that the market integration in two Districts was weak.

Granger Causality Test milk price in industry level in Dairy Bussiness Area, Pamijahan District nd Cisarua District are presented in Table 4. Based on the result of Granger Causality Test in Dairy Processing Industry level, probability of Fstatistic value Dairy Product Cooperative Bogor was smaller than $\alpha=5 \%(0.013<0.05)$ meaning that there was an effect of the changes of milk price in Dairy Product Cooperative Bogor to change of milk price in Giri Tani village unit cooperative. Based on the result of Granger
Causality Test, probability of F-statistic value of Giri Tani village unit cooperative was smaller than $\alpha=5 \%(0.002<0.05)$, meaning that there was an effect of the changes of milk price in Giri Tani village unit cooperative to change of milk price in Dairy Product Cooperative Bogor. From the result in Table 4 there was a two-way relation and reciprocal relation between Dairy Product Cooperative Bogor and Giri Tani village unit cooperative. In the result of Table 4 , it can be seen that there was an effect of the increase of milk price between Dairy Business Area, Pamijahan District and Cisarua District in Dairy Processing Industry Level. This result of the study is in accordance with Lemma and Singh (2015). It is indicated that the milk prices in two different locations are an integration price. In addition 
Table 4. Granger Causality Test Result Milk Price Dairy Processing Industry Level in Dairy Bussiness Area, Pamijahan District and Cisarua District

\begin{tabular}{|c|c|c|c|c|}
\hline Causality Correlation & Observation & Lag & F-statistic & Probability \\
\hline $\begin{array}{l}\text { Milk price industry level, Dairy Product } \\
\text { Cooperative Bogor influence milk price in Giri } \\
\text { Tani village unit cooperative }\end{array}$ & 20 & 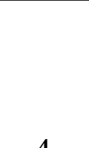 & 3.96392 & 0.01369 \\
\hline $\begin{array}{l}\text { Milk price industry level, in Giri Tani village } \\
\text { unit cooperative influence milk price in Dairy } \\
\text { Product Cooperative Bogor }\end{array}$ & 32 & 4 & 7.47692 & 0.00241 \\
\hline
\end{tabular}

Heytens (1986) stated that in integrated market system, there will be positive correlation between the price change at different market location. Research of Katrakilidis (2008) stated that the dynamic of milk price in short term, there is a dominating market where the market has influenced the milk price on the other market.

\section{CONCLUSION}

Based on the result of this research, it can be concluded that there was an effect of the increase of milk price between Dairy Business Area, Pamijahan District and Cisarua District in Dairy Processing Industry Level, meaning that there was an integration between the milk price in Dairy Processing Industry level and there was causality correlation in Dairy Business Area, Pamijahan District and Cisarua District. In Dairy Business Area of Pamijahan District and Cisarua District, the market system of integration ran efficiently. The markets were strongly integrated because there were changes of the increase of milk prices in both areas.

\section{REFERENCES}

Asmara, R and R. Ardhiani. 2010. Integrasi pasar dalam sistem pemasaran bawang merah. Agrise. X(3):164-176.

Barret, C, B. 2005. Spatial market integration. DiIn Lawrence E. Blume and Steven N. Durlauf $\left(2^{\text {nd }}\right.$ edition). The New Palgrave Dictionary of Economics, Plagrave Macmillan, London.

Dinas Peternakan and Perikanan Kabupaten Bogor. 2013. Data Statistik Peternakan Kabupaten Bogor Tahun 2013. Bogor, Jawa Barat.
Ghoshray, A and M. Ghosh. 2014. How integrated is the Indian Wheat Market? Journal of Development Studies. 47(10):1574-1594.

Heytens, P. J. 1986. Testing market integration. Food Res. Institute. 20(1):25-41.

Irawan, A and D. Rosmayanti. 2007. Analisis integrasi pasar beras di Bengkulu. J. Agro Ekonomi. 25(1):37-54.

Jha, A. K., K. M. Singh and R. K. P. Singh. 2013. Wholesale Milk Markets: A Study of Markets Integration in Indian Markets. Munic Personal RePEC Archive. P. 1-12.

Johansen, S and Juselius K. 1990. Maximum likelihood estimation and inference and cointegration with application to the demand for money. 52(2):169-210.

Katrakilidis, C. 2008. Testing for market integration and the law of one price: an application to selected Europan milk markets. International Jornal of Economic Research. 5(1):93-104.

Lemma, H. R and R. Singh. 2015. Testing for price co-integration between producer and retailers: evidence from Ethiopian milkmarket. Scientific Research Publishing. 7(1):1-9.

Mudikdjo, K., U. Sehabudin and R. Pambudy. 1994. Analisis ekonomi usaha ternak sapi perah di wilayah Propinsi Jawa Barat. Media Peternakan. 24(1):57-66.

Sarker, D and B.K. Ghosh. 2010. Milk Marketing Under Cooperative and Non-Cooperative Marketin Channels: Evidence From West Bengal. Economic Annals: LV(187):87-108.

Siswadi., Y. Subagyo and T. Y. Astuti. 2001. Analisis fungsi produksi susu pada usaha peternakan sapi perah rakyat di Kecamatan Sumbang, Banyumas. J. Anim.Prod. 3(1): 12-19. 